\title{
INTERPRETATION OF REFLECTION SEISMIC DATA FROM THE USANGU BASIN, EAST AFRICAN RIFT SYSTEM
}

\author{
EI Mbede \\ Department of Geology, University of Dar es Salaam, \\ P.O. Box 35052, Dar es Salaam, Tanzania
}

\begin{abstract}
Reflection seismic data collected by AMOCO Tanzania Oil Company in the 80 s, are herein used to correlate the main Usangu Basin parameters to those estimated from outcrop, gravity and aeromagnetic data. The seismic data are further used to constrain the geometry of crustal extension in this south-western sector of the East African Rift System (EARS) in Tanzania. Three distinct sedimentary packages on top of the basement reflector are interpreted and correlated to the Permo-Carboniferous Karoo rocks, the Jurassic/Cretaceous and Miocene Red Sandstone Group and Miocene to recent Lake Beds in the adjacent Rukwa basin, where the ages of the sedimentary sequences have been established on the basis of drill hole data.
\end{abstract}

The Karoo beds, deposited on an undulating weathered basement surface, are relatively thin $(\sim 200 \mathrm{~m})$. The Red Sandstone Group reach a maximum thickness of up to $420 \mathrm{~m}$ while the Lake Beds are up to $289 \mathrm{~m}$ thick. Beneath the Karoo, seismic reflections show interval velocities of $3.22 \mathrm{~km} / \mathrm{s}$, which are less than typical crystalline basement velocities of $4.2 \mathrm{~km} / \mathrm{s}$ in the adjacent Rukwa Rift. These "sub-basement" velocities are atributed to the slightly metamorphosed sediments of Upper Proterozoic, Buanji Group that crop out extensively on top of the Chimala scarp. Previous estimate of the thicknesses of Buanji sediments from outcrop data has been up to $1.086 \mathrm{~km}$. The present study, however, suggest a thickness of more than $2 \mathrm{~km}$ for the Buanji sediments beneath the Mesozoic to recent sediments in the Usangu Basin. Age wise the Usangu Basin, which has always been considered to be much younger than its south-western continuation, the Luangwa valley, is here suggested to be an old structure in which sedimentation has been going on since Karoo time. Recent faulting mechanism inferred from recent earthquake data and the present interpretation of seismic sections suggest that deformation in the Usangu Basin has been predominantly strike slip. Thus, the Usangu Basin is best interpreted as a transfer fault, accommodating the relative movement between the southern-most sub-basin of the Rukwa Rift and the northernmost sub-basin of the Malawi Rift. 


\section{INTRODUCTION}

The Usangu Basin is a NE-SW trending basin located at the junction of the northern end of Malawi rift and the southern termination of the Rukwa rift (Fig. 1). The basin, which is an area of recent deposition, is drained to the $\mathrm{NE}$ by tributaries of the great Ruaha river. On a regional scale, the Usangu Basin is the continuation of the Luangwa valley bisecting the TanganyikaRukwa-Malawi (TRM) fault zone. The extension direction in this part of the EARS remains controversial. On the basis of kinematic indicators recorded in the basement rocks of the rift flanks, the TRM fault zone has been interpreted to be a transform fault zone offsetting the Usangu Basin and the Luangwa valley (Chorowicz \& Mukonki 1979, Chorowicz et al. 1987, Tiercelin et al. 1988, Kilembe \& Rosendahl 1992, Wheeler \& Karson 1989, 1994). Accordingly, these workers consider regional extension in this area to be mostly in the NW direction. A NW extension direction is also supported by shallow earth quake data (Shudofsky 1985, Shudofsky et al. 1987, Cammelbeeck \& Iranga 1996) which suggest that faulting in the MalawiRukwa rift zone is predominantly strike-slip. Other workers, however, have proposed an E-W to ENE-WSW extension direction (Morley 1989a, b, Strecker et al. 1990). On the basis of the large and deep earthquakes recorded within the Malawi and Rukwa rifts, Jackson and Blenkinsop (1993) and Foster et al. (1995) have proposed that crustal failure within the southern part of the western arm of the EARS occurs along purely normal faults. Such a failure mechanism would suggest that regional extension within the area occurs predominantly in the NE-SW to ENE-WNW directions, that is, parallel to the Usangu Basin bounding faults. If this is the case, then the Usangu Basin can be interpreted to be an accommodation zone between the southernmost basin within the Rukwa rift (the Songwe Basin) and the northernmost basin within the Malawi rift (the Livingstone Basin). In the Usangu Basin, however, the most recent extensive phase of deformation appears to be nearly radial whereas deformation during the Pliocene appears to have been purely strike-slip (Delvaux et al. 1992). This would suggest that the Usangu Basin may only have acted as an accommodation zone between the Malawi and Rukwa rifts during Pliocene. Such an interpretation would be consistent with kinematics indicators from both rift flanks and infilling rocks within the Malawi-Rukwa Rift zone which suggests a change of stress orientation with time in this southern most part of the EARS (Delvaux et al. 1992, Ring et al. 1992, Mbede 1993).

In the present paper, correlations has been made of the main basin parameters obtained using seismic reflection data to those estimated from outcrop (Ebinger et al. 1989) and gravity data (Marobhe \& Mbede 1996). In addition use has been made of the seismic reflection data to further constrain the geometry of crystal extension in this south-western sector of the EARS in Tanzania. Observations in the seismic sections suggest more than $3 \mathrm{~km}$ of sedimentary units. The current interpretations are consistent with Marobhe and Mbede's (1996) interpretations of gravity data and Anon's (1988) 
interpretation of gravity and magnetic data that lead to the acquisition of seismic reflection data.

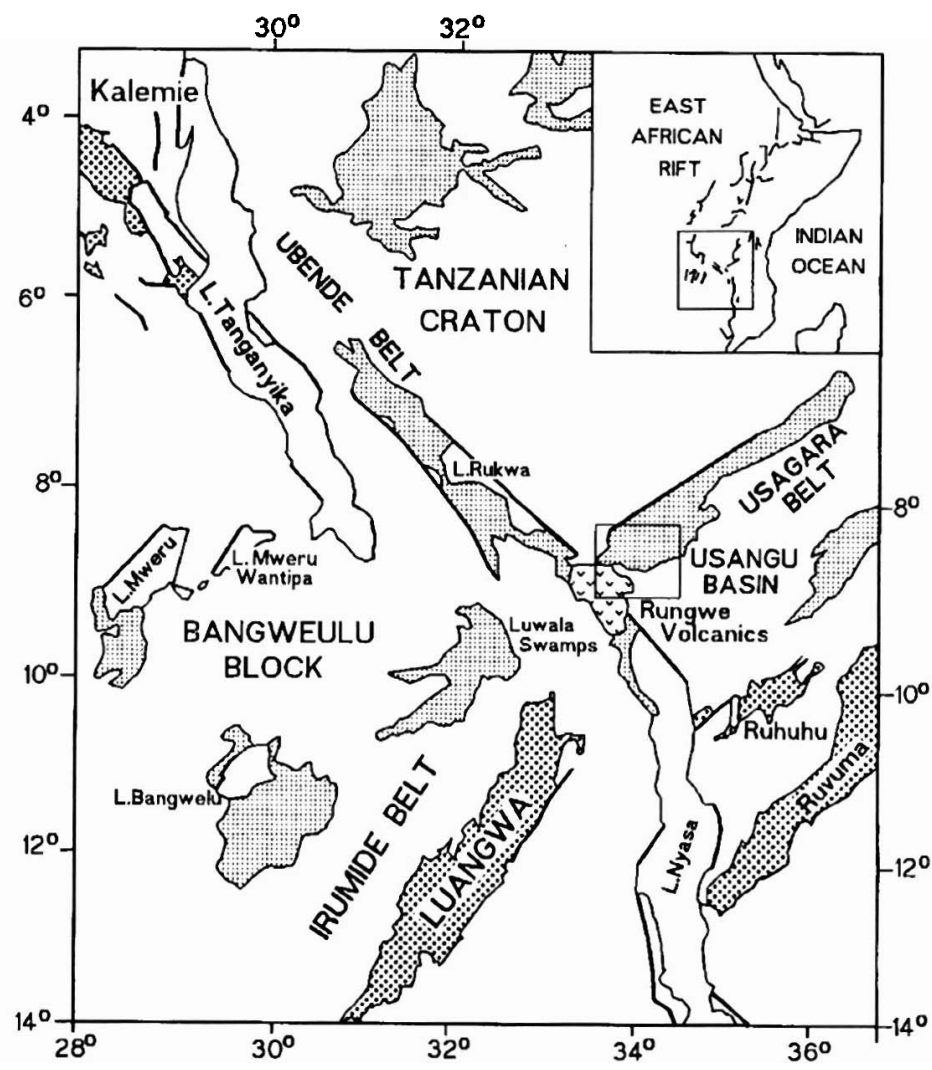

\section{Major Rift Faults Cenozoic volcanic Karoo Sediments}

Fig. 1: Regional tectonic map of the western branch of the EARS showing the study area and relationship of Karoo, Cenozoic basins and the mobile belts surrounding the basins (After Delvaux et al. 1992)

\section{Geology and Tectonic Setting}

The NE-SW trending Usangu Basin (Fig. 1) is enclosed between latitudes $8^{\circ}$ $06^{\prime} \mathrm{S}$ to $9^{\circ} 06^{\prime} \mathrm{S}$ and longitudes $33^{\circ} 36^{\prime} \mathrm{E}$ to $34^{\circ} 36^{\prime} \mathrm{E}$. The basin is bound on the west and northwest by a system of N-S striking step faults rising to the level of the uplifted Usangu fault scarp. The south and south-eastern margin is marked by the Chimala fault scarp (Fig. 2). To the SW, lava flows off the Rungwe volcanic province crop out within the basin, while north-eastwards the basin merges with the eastern arm of the EARS as the Usangu fault scarp and the rift in general fade away into central Tanzania. South of the Chimala 
scarp, the basin is flanked by the weakly metamorphosed rocks of the Buanji Group that belong to the Bukoban system of Upper Proterozoic (Harpum \& Brown 1958). Rocks of the Buanji Group, in turn, overlie a sequence of rocks ranging from the Middle Proterozoic low grade metasediments of the Ukingan Group and associated granites to the Early Proterozoic Ubendian gneisses (Quenelle et al. 1956). Towards the west, the Chimala scarps dies out as its remnants are draped over by Neogene volcanics of the Rungwe volcanic province (Harkin 1960). In the north, the Usangu Basin is flanked by the Early Protezoic Ubendian gneisses of the Lupa Block. The basement rocks of the Lupa Block can be distinguished into two main groups. The first group is composed of metagabbros, metaperidotites and migmatitic granitic gneisses which crop out in the western part of the Lupa block. The second group, which forms most of the eastern part of the block, consists predominantly of granitic rocks (Marobhe \& Mbede 1996).

\section{METHODS}

Three migrated dip reflection seismic sections and one section along the basin have been used in this study. The location of seismic sections is shown on Figure 2. These data are part of the seismic records acquired between 1985 and 1986 by the Western Geophysical Company for AMOCO Tanzania Oil Company with the aim of constraining the subsurface structure of the Usangu Basin following the discovery of thick sedimentary sequences within the basin (Anon 1988), using gravity and aeromagnetic data. Data acquisition was done using vibrator type LRS 309 as source at $50 \mathrm{~m}$ intervals. Recording was done in 64 fold coverage using instrument type GSU SER III with 128 channels. Geophones type LRS $1011,10 \mathrm{HZ}$ responding at a group interval of $50 \mathrm{~m}$ were used. Data processing was done by Companie General de Geophysique (CGG) in Nairobi (Kenya). Final structural stack and migrated data were used in the present study.

Interpretation of the sections involved structural data identification and calculation of sedimentary thicknesses using the two way travel times shown on the migrated sections. The migrated sections have been reduced photographically to produce the figures presented in this paper.

\section{RESULTS}

\section{Basin parameters}

The bouguer anomaly map of Usangu basin (Fig. 3, Marobhe \& Mbede 1996) clearly outlines the basic basin configuration which displays a single basin separated by the NS trending basement high at the middle of the basin. This basement high is inferred to as the continuation of the Mkondo shear zone that crop out on the Lupa block north of Usangu Basin. Mkondo shear zone is basically due to density contrast of lithologic units indicating low gradient anomalies over the granitic basement in the east and high relief gravity anomalies attributed to the more basic basement in the western part of 
Lupa block (Marobhe 1989). Figure 3 is the seismic section line TVZ 34 shot, along the basin. Like the gravity data, line TVZ34 running for about 58 $\mathrm{km}$ along the basin suggests a single basin structure. I therefore interpret Usangu Basin as a single basin structure. The three dip seismic sections TVZ 35, 36 and 37 (Figs. 4, 5 and 6), shot across the basin were primarily intended to further constrain the thickness of the sedimentary units adjacent to the Usangu Border Fault System inferred from gravity and magnetic data interpretation (Anon 1988).

Three distinct reflectors are interpreted, which represent three separate sedimentary packages above the basement. The lowermost sedimentary package overlies the basement with a distinct unconformity. This package is characterised by strong reflections of high amplitude suggestive of well bedded and indurated sediments. In the adjacent Rukwa rift, drill hole data indicate that such strong and high amplitude reflections are associated with Permo-Carboniferous Karoo rocks (Kilembe \& Rosendahl 1992, Mbede 1993).

On the basis of this similarity, the lowermost sedimentary package in the Usangu basin is interpreted as also being of Karoo age. In the Rukwa rift, velocities of Karoo sediments along line TVZ 07 adjacent to Ivuna well vary between $2.88 \mathrm{~km} / \mathrm{s}$ and $2.35 \mathrm{~km} / \mathrm{s}$, similar to those recorded in the Karoo section of the Usangu basin. Along the basin, on line TVZ 34, the Karoo section appears to be thickest on the western part of the basin thinning over the adjacent basement high before thickening again in the middle part of the basin and pinching out at shot point 1730 .

The thickness of the Karoo section over this stikeline is on the average 200 $\mathrm{m}$. On the dip sections (figure 4, 5 and 6) Karoo section is missing on line TVZ 35 on the easternmost part of the basin suggesting a depocenter dipping westwards. On lines TVZ 36 and TVZ 37, Karoo sections tend to thicken northwards adjacent to the Usangu border Fault System. This suggest synsedimentary faulting at that time and the Usangu fault may have acted as a border fault system since Karoo time. The nature of the unconformity is wavy and undulating suggesting a weathered basement topography (Fig. 5). Maximum thickness of Karoo on line TVZ 36 is $264 \mathrm{~m}$ while on line TVZ37 it is up to $289 \mathrm{~m}$.

The second sedimentary package overlies the Karoo with a distinct unconformity and is generally thicker than the underlying sediments. Reflections in this section are characteristically of medium amplitude with evidence of bedding traces similar to those observed in the Red Sandstone Group (RSG) of the adjacent Rukwa rift (Kilembe \& Rosendahl 1992, Mbede 1993). 


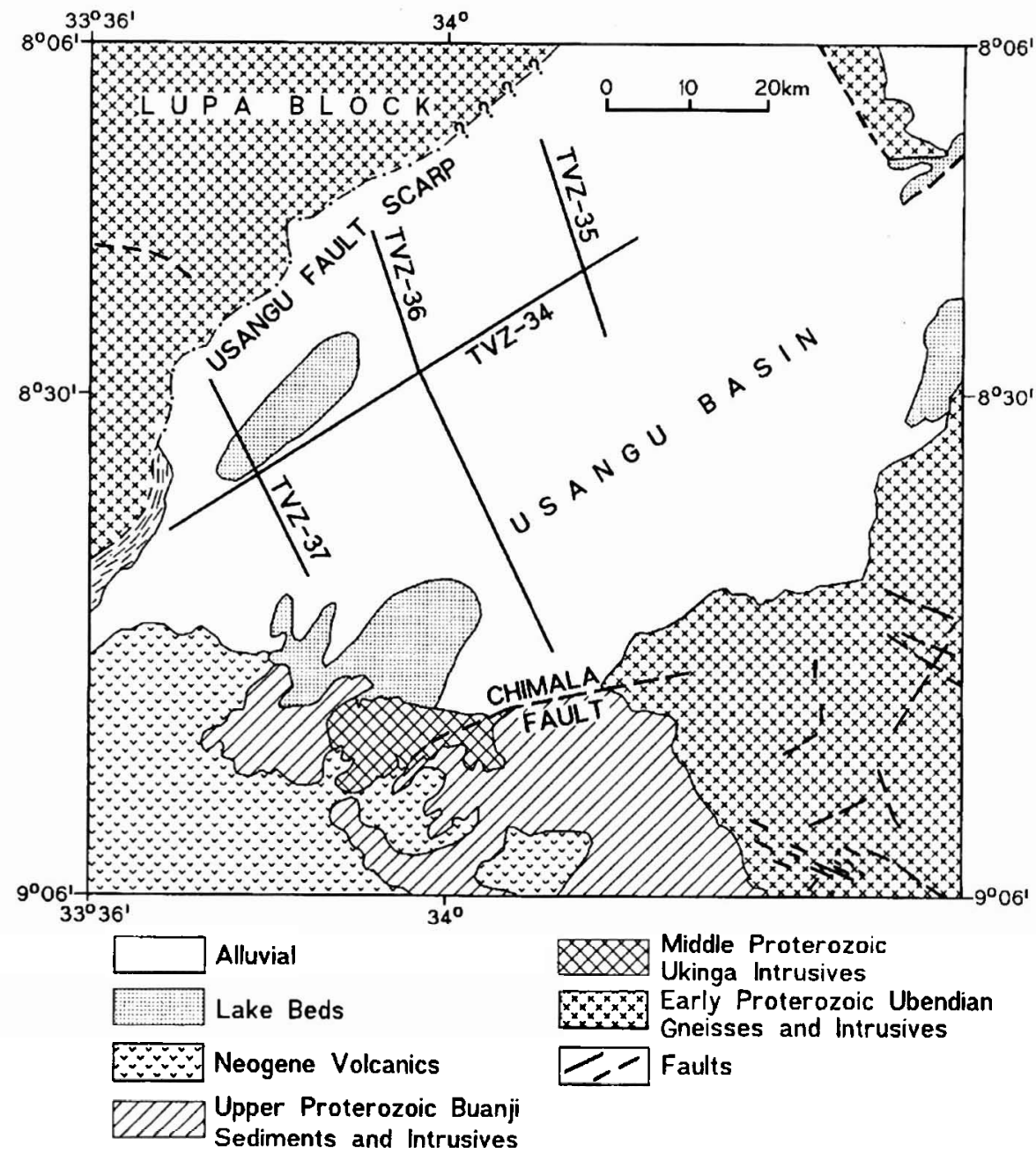

Fig 2: Geology of the Usangu Basin and the surrounding area with locations of seismic area and locations of seismic lines described below (modified after Marobhe 1989)

On the basis of this analogy, the sediments overlying the Karoo in the Usangu Basin are interpreted to be correlatives of the Rukwa rift RSG. Seismic velocities vary between $2.25 \mathrm{~km} / \mathrm{s}$ and $1.77 \mathrm{~km} / \mathrm{s}$ and are comparable to those found in the RSG along line TVZ 07 in the Rukwa rift adjacent to the Ivuna well. Along the basin, on line TVZ 34, the RSG show a general westwards thickening trend suggesting a basinwide westward depocenter. The average thicknesses of RSG on this line is up to $300 \mathrm{~m}$ (Fig. 3). On dip sections the RSG tend to thicken towards the bounding fault suggesting synsedimentray faulting at the time. 


\section{Line TVZ 34}
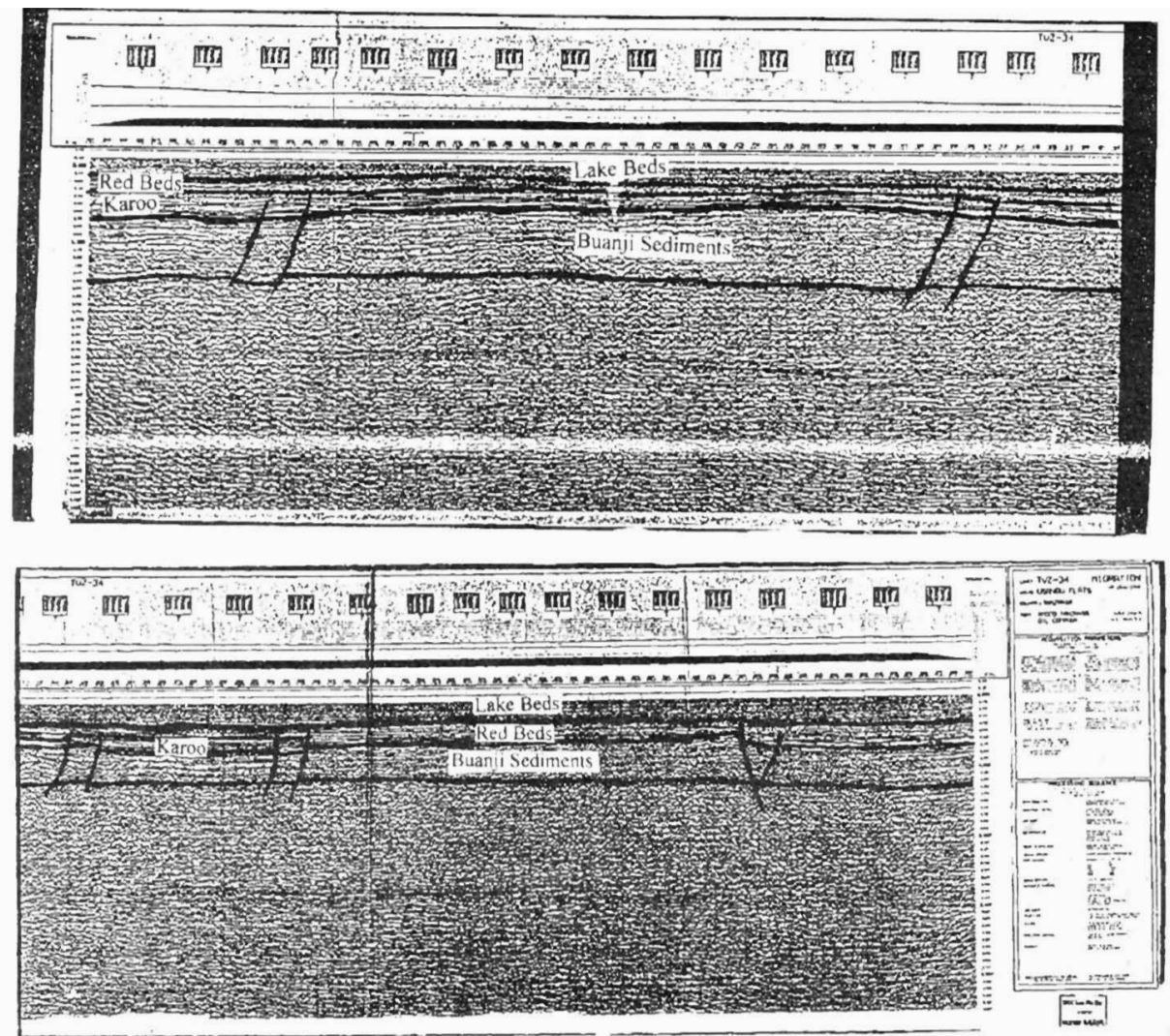

Fig. 3: Reflection seismic section line TVZ 34 shot along the basin. Note the nature o block faulting. See Fig 2 for location

\section{Line TVZ 35}

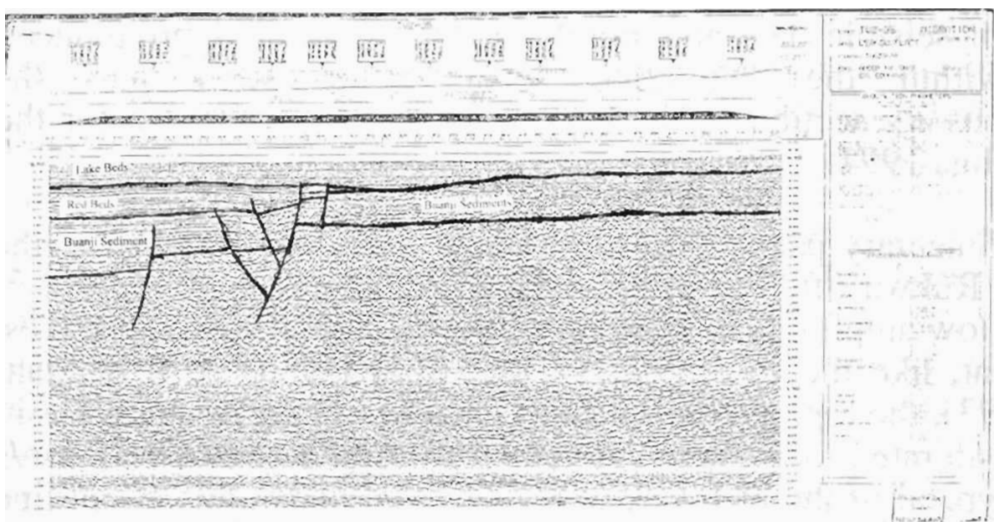

Fig. 4: Reflection seismic section line TVZ 35 shot across the basin. See Fig. 2 for Iocation 


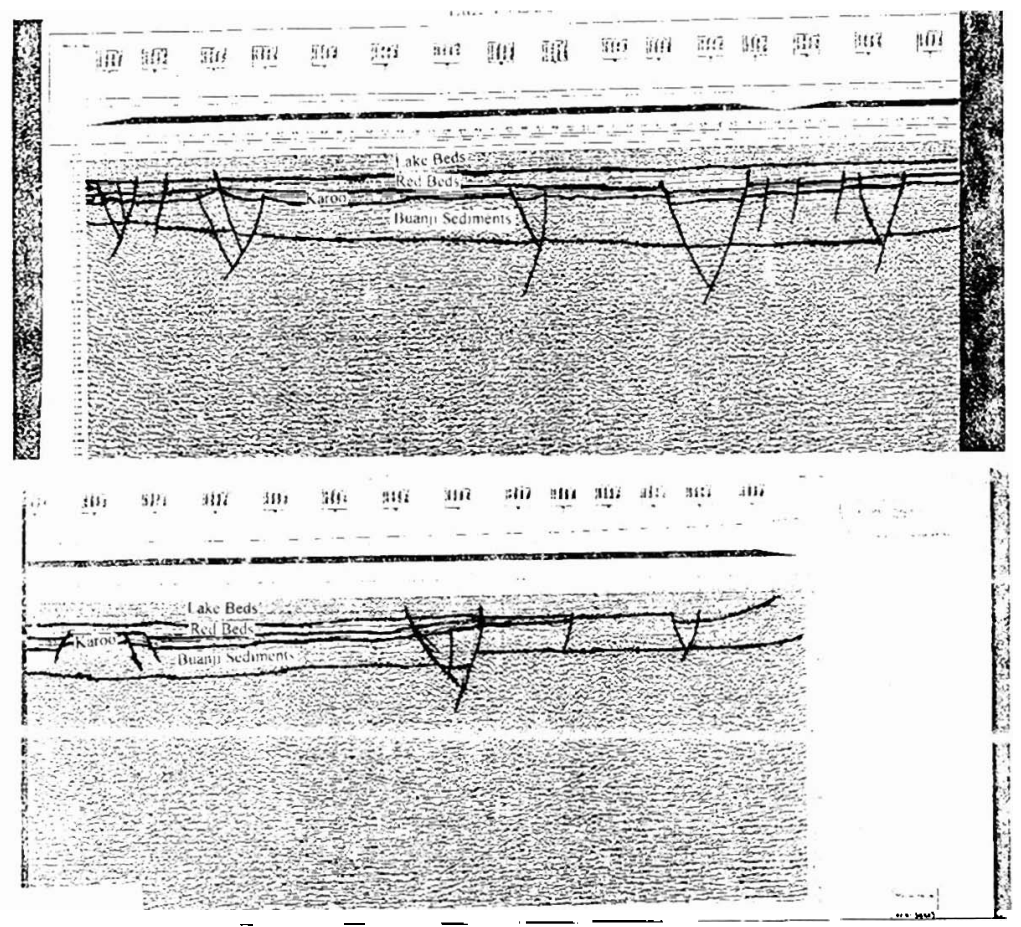

Fig. 5: Reflection seismic line TVZ 36 shot across the basin. Note the undulating nature of the basement reflector and the reverse nature of the block faults. See Fig. 2 for location

Thicknesses of up to $410 \mathrm{~m}$ are recorded in the westernmost part of the basin along line TVZ 37 (Fig. 5), whereas along line TVZ 35 on the easternmost part of the basin, recorded maximum thicknesses are up to $300 \mathrm{~m}$ (Fig. 3). In the adjacent Rukwa basin the RSG has in the past been controversially dated as either Jurassic/Cretaceous (McConnel 1951, Smirnov et al. 1974, Sirvastava 1988) or Neogene (Wescot et al. 1989). However, recent reinterpretation of seismic data and borehole data suggest a pronounced unconformity within the unit that separate the RSG into the Jurassic/Cretaceous age section on the lower part and Noegene age for the upper section (Mliga 1994).

The topmost sedimentary package in the Usangu basin is correlated to the Lake beds in the Rukwa rift. The volcanoclastic sediments that crop out in Usangu produce low amplitude reflections with evidence of bedding traces. This suggests that, like the Lake beds in Rukwa (Kilembe \& Rosendahl 1992, Mbede 1993), the topmost sedimentary package in the Usangu Basin consists of less indurated rocks. Interval velocities vary between $1.75 \mathrm{~km} / \mathrm{s}$ and $1.55 \mathrm{~km} / \mathrm{s}$, typical of the Neogene to recent Lake beds units along line TVZ 07 adjacent to Ivuna well. Thicknesses of the Lake beds in Usangu basin reach a maximum of $347 \mathrm{~m}$. 
Beneath the Karoo, up to a two way travel time of 0.8 seconds, seismic reflections show interval velocities of $3.22 \mathrm{~km} / \mathrm{s}$, which are less than typical basement velocities of $4.2 \mathrm{~km} / \mathrm{s}$ recorded along line TVZ 07 adjacent to the Ivuna well in Rukwa. These "sub-basement" velocities are attributed to the weakly metamorphosed sediments of the Buanji Group that crop out extensively on top of the Chimala scarp (Fig. 2). According to this interpretation, the Karoo rocks in the Usangu basin are separated from true high grade metamorphic basement by the weakly metamorphosed sediments, the Upper Proterozoic Buanji Group. Harpum and Brown (1958) estimate the total thickness of the Buanji Group at about $1086 \mathrm{~m}$ from outcrop data. The present study, however, suggests more than $2000 \mathrm{~m}$ for the Buanji sediments beneath Mesozoic to recent sediments in the Usangu Basin. Along the basin, on line TVZ 34 (Fig. 3), the thickness of Buanji sediments vary between 740 $\mathrm{m}$ and $1386 \mathrm{~m}$. Dip sections, along lines TVZ 35, 36 and 37, show thick sequences of Buanji sediments towards the northern end of the basin, adjacent to the Usangu fault scarp, but the sediments do not show progressive thickening towards the bounding fault. Along line TVZ 37 in the westernmost part of the basin, Buanji sediments are up to $1844 \mathrm{~m}$ thick (Fig. 6). Similarly from figure 5, along line TVZ 36, thicknesses of Buanji sediments reach a maximum thickness of $1056 \mathrm{~m}$. In the eastern-most part of the basin, along line TVZ 35 (Fig. 4), Buanji sediments reach a maximum thickness of 2039 $\mathrm{m}$. This indicates that the Buanji sediments in this basin tend to thicken in the Eastward direction contrary to the Mesozoic to recent section that suggest a basinwide Westward depocenter at the time. A more than $2 \mathrm{~km}$ package of Buanji sediments beneath the Karoo rocks make the total thickness of the Usangu sedimentary column as estimated from reflection seismic sections about $3.085 \mathrm{~km}$, closer to the $3.5 \mathrm{~km}$ estimated by Marobhe and Mbede (1996) using gravity data. The suggested stratigraphy of the Usangu Basin is shown on figure 7 .

\section{Deformation style}

An analysis of the seismic data from the Usangu basin indicates that faulting has been largely concentrated in the southern part of the basin close to the Rungwe volcanic province. The dip seismic sections (Figs. 4, 5 and 6) also show evidence of thickening towards the bounding fault suggesting synsedimentary faulting at the various stages of rift development. Unlike the Rukwa basin, where most of Karoo faults have been reactivated during Late Tertiary rifting, a good number of Karoo faults in the Usangu basin terminate within the Red Sandstone Group. This indicates that the current rift development in this basin must have commenced during Karoo time. The fact that most of the Karoo faults terminate within the RSG, probably suggests that the RSG in this basin belong to the Mesozoic age. This lack of reactivation of intrabasinal Karoo faults during Late Tertiary rifting, is supported by the paucity of recent earthquake activity in the Usangu basin relative to the adjoining basins (Iranga 1991). The dip seismic sections (Fig. 
4, $5 \& 6$ ) further indicate that within the Usangu basin, faults are typical sequences of normal faults with significant heaves missing. Such faults would be expected if deformation was mostly accommodated by maximum extension across the basin. Instead, the reflection data indicate that most deformation was accommodated through reverse block faulting associated with a few flower structures suggestive of strike-slip deformation (Figs. 4, 5 and 6).

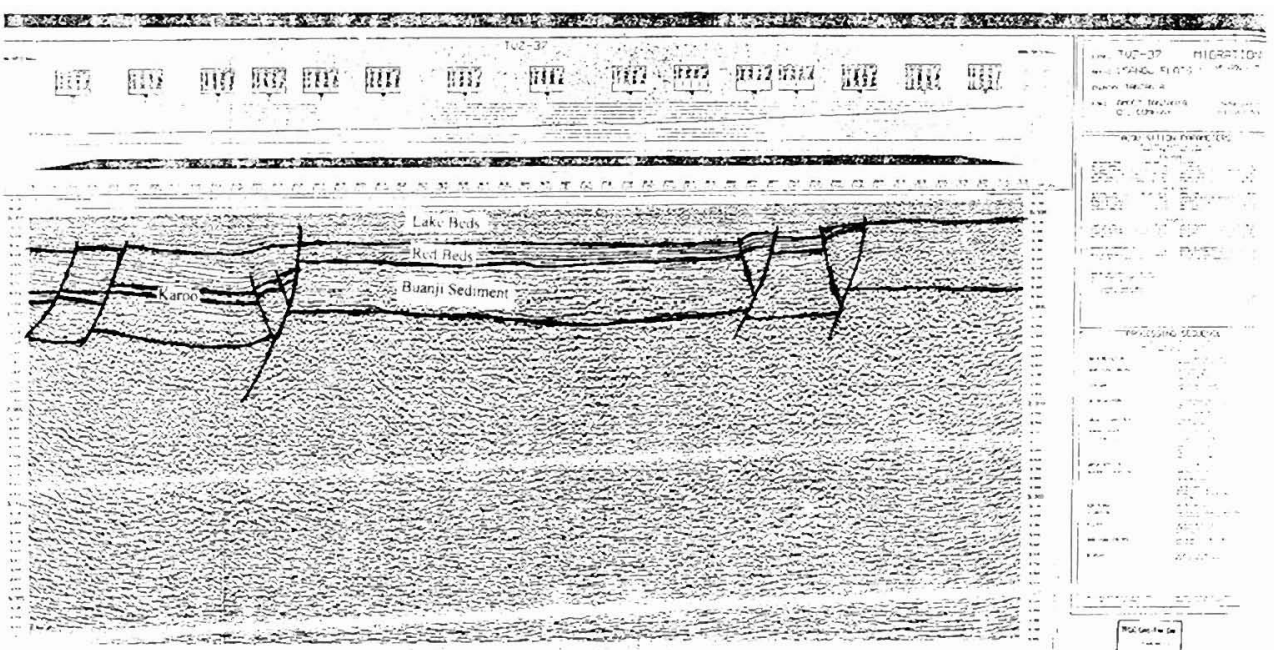

Fig. 6: Reflection seismic section line TVZ 37 shot across the basin. See Fig. 2 for location

The absence of typical extension structures complimented by the presence of typical flower structures strongly suggest that deformation in the Usangu basin has been predominantly strike slip. This interpretation is consistent with that of Ebinger et al. (1989) who consider the Usangu basin to be a zone accommodating the relative movement between the southern-most basin of the Rukwa rift and the northern basin of the Malawi rift.

\section{DISCUSSION}

Usangu basin is a rift basin similar in geometry and shape to the other rift basins within the EARS. The present seismic data interpretation complimented by gravity data interpretation of Marobhe and Mbede (1996) suggest that maximum sediment deposition during the Mesozoic and Tertiary occurred northwards and north-westwards towards the bounding Usangu Fault scarp. Seismic sections of Mesozoic to Tertiary rift faulting tend to thicken northwards towards the Usangu border fault. The Usangu fault scarp itself rises up to $1 \mathrm{~km}$ above the basin level while the high flank uplift of the Chimala scarp, on the ramping side of the basin, has mainly been attributed to the isostatic response of the eastern bounding fault of the Malawi rift and the Livingstone Boarder Fault system (Van der Beek et al. 1996). 


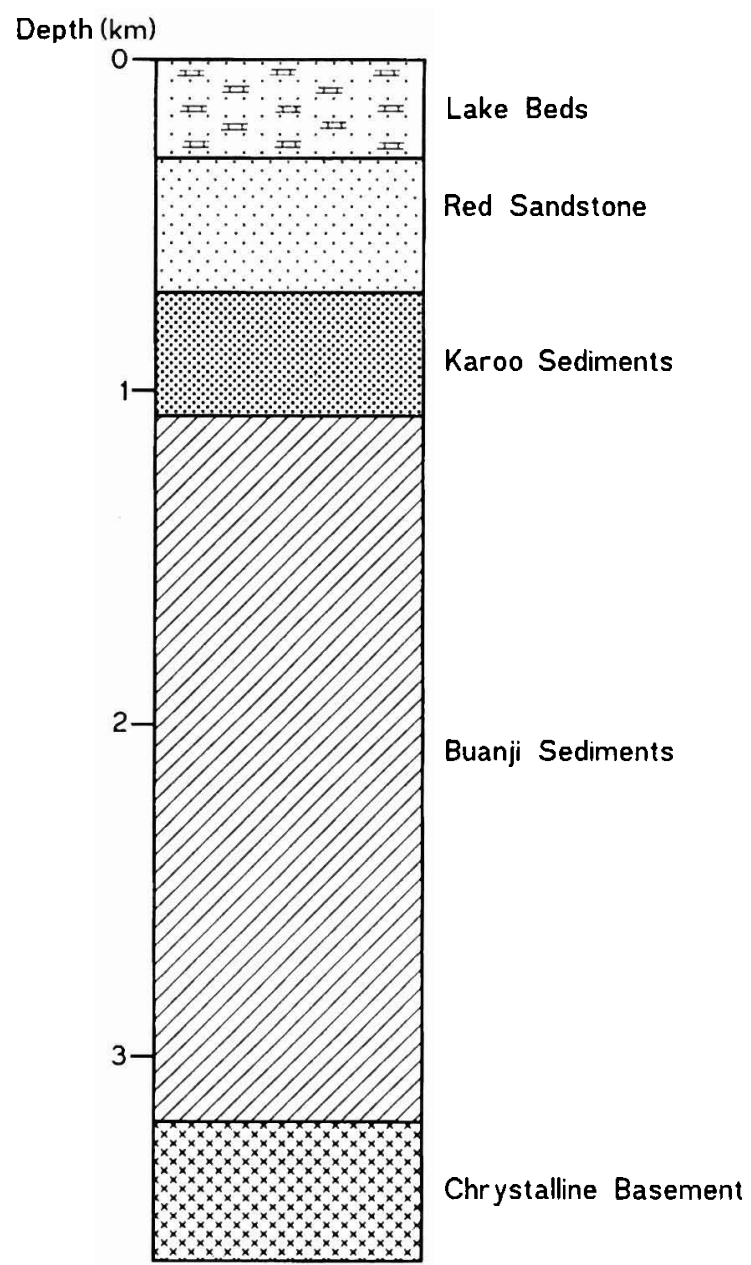

Fig. 7: Summary of the stratigraphy of the Usangu basin, Tanzania

In the past, thicknesses of sedimentary units have been estimated from outcrop studies and up to $2 \mathrm{~km}$ of sedimentary units were inferred beneath the present surface (Ebinger et al. 1989). Interpretation of aeromagnetic data within Usangu had suggested sediment thicknesses of up to $1.6 \mathrm{~km}$ in some places (Marobhe 1989). Gravity data analysis (Marobhe \& Mbede 1996) suggests a maximum of $3.5 \mathrm{~km}$ of sedimentary units at the basin depocenter adjacent to the Usangu border fault system. The present seismic interpretation suggests a more than $3 \mathrm{~km}$ of sediments in the areas traversed by the current seismic data. These thicknesses are much closer to the $3.5 \mathrm{~km}$ of sediments suggested by the gravity data interpretation of Marobhe and Mbede (1996). Though the Mesozoic to recent sedimentary package is only up to a $\mathrm{km}$, the slightly metamorphosed Buanji sediments are imaged as sedimentary packages in the gravity data interpretation. This interpretation is consistent 
with those of AMOCO Tanzania Oil Company (Anon 1988) that lead to the shooting of seismic data in this basin.

The age of the Usangu Basin has been poorly constrained in the past. Ebinger et al. (1989) suggest that the development of the Usangu fault scarp was initiated during early Pliocene after the initial volcanism within the Rungwe volcanic province. In this way the whole sedimentary package on top of the basement is interpreted as Pliocene to recent. The current seismic data interpretation differ with these interpretations on three grounds. The degree of induration of sediments in the basin is much greater than sediments normally deposited during Late Tertiary Rifting in the adjacent Rukwa rift. As a result the seismic velocities at the base of the sediment section are not typical of the late Tertiary rifting sediments in the adjacent Rukwa rift. Faulting termination within the Mesozoic section of the sediment package implies a multiple phase of rifting. Recent geochronological work (Ivanov et al. 1998, Ivanov et al. 1999) suggest that late Tertiary volcanism with the Rungwe province started in early Miocene and the oldest volcanic rocks within the Usangu basin are 17.3 ma. Field relationships suggest that sedimentation within the Usangu basin occurred mainly prior to the early Miocene phonolite intrusion because the phonolitic bodies intrude into the lake beds. Sediment packages beneath the Miocene lake beds suggest that Usangu basin, like most basins in the western rift, has been an area of deposition since Karoo time.

The slightly metamorphosed Buanji sediments, which underlie Karoo rocks, constitute the oldest sedimentary package imaged in the Usangu basin. The Upper Proterozoic Buanji sediments in this basin lies on top of Precambrian crystalline basement rocks with a distinct unconformity. The seismic data further suggest that the Buanji sediments beneath the Usangu basin represent the thickest preserved column of these Late Proterozoic rocks in southwestern Tanzania. The unconformity beneath the Karoo is wavy and undulating and traces of Karoo faults cannot be seen in the underlying sediments. This suggest that the Buanji sedimentation was not controlled by the present fault pattern in the basin and the development of the current Usangu basin must have been initiated during Karoo time. Our seismic reflection data suggest that faults in the Usangu basin have been active at least since the Permo-Carboniferous time when Karoo rocks were deposited. The thin Karoo unit sediment package implies large period of quietness uplift and erosion prior to the next phase of faulting. Some of the Karoo faults have been reactivated during Tertiary Rifting, while others do terminate within the Red Sandstone Group suggesting that the Red Sandstone Group here also belongs to the Mesozoic age.

\section{ACKNOWLEDGEMENT}

Many thanks are due to Mr Mwalyego, the then Director of Exploration, TPDC, for making the Usangu data available as part of University of Dar es 
Salaam teaching material. The manuscript benefited from comments of several anonymous reviewers.

\section{REFERENCES}

Anon. 1988 Assessment on the hydrocarbon prospectively of the Lake Rukwa basin, Tanzania. Amoco Tanzania Unpublished internal reports to TPDC

Camelbeek T and Iranga MD 1996 Deep crustal earthquakes and geometry of active faults along the Rukwa-Malawi rift zone, eastern Africa. Geophy. J. Int. 124: 612-630

Chorowicz J and Mukonki NMB 1979 Linéaments anciens, zones transformantes récentes et géotectonique des fossés de l'Est africain, d'après la télédétection et la microtectonique. Mus. Roy. Afr. Centr., Dépt. Geol. Min. Rapp. Ann. 143-167

Chorowicz J, Lefournier J and Vidal G 1987 Model of the rift development in Eastern Africa. Thematic issue Geol. J. 22: 495-513

Delvaux D, Levi K, Kajara R and Sarota J 1992 Cenozoic pleostress and kinematic evolution of the Rukwa-North Malawi rift valley (East African Rift System). Bull. Cent. Rech. Explor. Prod. ElfAquitaine 16: 383-405

Ebinger CJ, Deino A, Drake B and Tesha AL 1989 Chronology of volcanism and Rift basin propagation: Rungwe volcanic province, East Africa.J. Geophy. Res. $94: 15785-15803$

Foster AN, Jackson JA and Ebinger CJ 1995 Source mechanism and centroid depths of recent earthquakes; African earthquakes. Terra (EUG) Abs. 7: 35

Harkin DA 1960 The Rungwe volcanics at the northern end of L. Nyasa. Geol. Surv. Tang. Memo 11: 172

Harpum JR and Brown PE 1958 The brief explanation of the geology of Chimala. Geol. Sur. Tang. QDS 246

Iranga MD 1991 An earthquake catalogue for Tanzania, 1846-1988. Seism. dept. rept. no 1-91 $80 \mathrm{pp}$

Ivanov AV, Rasskazov SV, Boven A, Andre A, Maslovskaya L and Temu EB 1998 Late Cenozoic alkaline-ultrabasic and alkaline basaltic magmatism of the Rungwe province, Tanzania. Petr. 6: 208-229

Ivanov AV, Rasskazov SV, Boven A, Punzalan L Brandt IS Brandt, SB and Fernandez-Alfonso M 1999 Timing of Late Cenozoic volcanic activity and rift basin formation in the Rungwe province of Tanzania substantiated by $K$-Ar and ${ }^{40} \mathrm{Ar} /{ }^{39} \mathrm{Ar}$ dating. Proceeding of the 3rd Annual meeting of the IGCP Project 400: Irkutsk (Russia) 75-79

Jackson J and Blenkinsop T 1993 The Malawi earthquake of March 10, 1989: Deep faulting within the East Africa Rift System. Tectonics 12/3: 1131-1139

Kilembe EA and Rosendahl BR 1992 Structure and stratigraphy of the Rukwa Basin. Tectonophy. 209: 143-158 
Marobhe IM 1989 Interpretation of aerogeophysical anomalies of southwestern Tanzania, Geol. Surv.Fin. Bull. 350: 72

Marobhe IM and Mbede EI 1996 Gravity data interpretation of the Usangu Basin, Tanzania. Tanz. J. Sc. 21: 56-66

Mbede EI 1993 Tectonic Development of the Rukwa Rift Basin in SW Tanzania. Berliner Geowissenschaftliche Abhandlungen Reihe A Band 152: 92

McConnel RB 1951 Outline of the geology of Ufipa and Ubende. Geol. Surv. Tang. 19:61

Mliga NR 1994 Depositional environments, stratigraphy and hydrocarbon potential of the Rukwa Rift Basin - SW Tanzania. Ph D thesis Duke University $156 \mathrm{pp}$

Morley CK 1989a Extension, detachments and sedimentation in continental rifts with particular reference to East Africa. Tectonics 8: 11751192

Morley CK 1989b Reply. Tectonics 8: 651-653

Quenelle AM, Mackinlay ACM and Aitken WG 1956 Summary of the Geology of Tanganyika, Part I: Introduction and stratigraphy. Geol. Surv. Tang. 264pp

Ring U, Betyler C and Delvaux D 1992 Normal vs strike-slip faulting during rift development in East Africa: The Malawi rift. Geol. 20: 10151018

Shudofsky GN 1985 Source mechanisms of focal depths of East African earthquakes using Rayleigh wave dispersion and body wave modelling. Geophy. J. Roy. Astr. Society 83: 563-614

Shudofsky GN, Cloetingh S, Stein S and Wortel R 1987 Unusually deep earthquakes in East Africa: constraints on thermo-mechanical structure of a continental rift system. Geophy. Res. Lett. 14: $741-744$

Sirvastava V 1988 Biostratigraphy of Ivuna well, in the Rukwa Rift Basin, from the interval 2500'-7600'. Report to the Tanzania Petroleum Development Co-operation, Dar es Salaam, 13pp

Smirnov V, Pentelcov V, Tolochov V, Trifan M and Zhukov S 1974 Geology and minerals of the central part of the western rift. Report to Minister, Research Division, Ministry of Commerce and Industries, Tanzania, 325pp

Strecker MR, Blisniuk PM and Eisbacher GH 1990 Rotation of extension direction in the central Kenya Rift. Geol. 18: 299-302

Tiercelin JJ, Chorowicz J, Bellon H, Richert JP, Mwambene JT and Walgenwitz F 1988 East African Rift System: offset, age and tectonic significance of the Tanganyika-Rukwa-Malawi intracontinental transcurrent fault zone. Tectonophy. 148: 241252

Van der Beek P, Mbede EI, Andriessen P, and Delvaux D 1998 Denudation of the Malawi and Rukwa Rift flanks (East Africa Rift System) 
from apatite fission track thermochronology. J. Af. Earth Sc. 26 (3): 363-385

Wescott WA, Krebs WN, Engelhardt DW and Cunningham SM 1991 New biostratigraphic age dates from the Lake Rukwa rift basin in western Tanzania. Am. Ass. Pet. Geol. Bull. 75(7): 1255-1263

Wheeler WH and Karson JA 1989 Structure and kinematics of the Livingstone mountains border fault zone, Nyasa (Malawi) Rift, south-western Tanzania. J. Afr. Earth Sc. 8: 393-413

Wheeler WH and Karson JA 1994 Extension and subsidence adjacent to a "weak" continental transform: an example from the Rukwa rift, East Africa. Geol. 22: 625-628 